See discussions, stats, and author profiles for this publication at: https://www.researchgate.net/publication/335527379

\title{
TINJAUAN ATAS PENGELOLAAN MUTASI BANK PADA KOPERASI SEJAHTERA BERSAMA (KSB) SB FINANCE CABANG PADJAJARAN BOGOR
}

\author{
Thesis · November 2013 \\ DOI: $10.13140 /$ RG.2.2.34495.05286 \\ CITATIONS \\ 2 authors, including:
}

Siti Ita Rosita

Sekolah Tinggi Ilmu Ekonomi Kesatuan, Indonesia, Bogor

26 PUBLICATIONS 107 CITATIONS

SEE PROFILE

Some of the authors of this publication are also working on these related projects:

Project Accounting Project View project 


\title{
TINJAUAN ATAS PENGELOLAAN MUTASI BANK PADA KOPERASI SEJAHTERA BERSAMA (KSB) SB FINANCE CABANG PADJAJARAN BOGOR
}

\author{
DEWI ANGGREINI \\ SITI ITA ROSITA.
}

\section{ABSTRAK}

Koperasi sebagai salah satu pelaku ekonomi juga dituntut untuk menjadi lebih profesional dalam proses pelayanan terhadap nasabah, maka harus ditunjang dengan pengelolaan keuangan yang baik pula. Di dalam perusahaan, pengelolaan kas yang baik sangatlah penting karena pengelolaan kas dapat dianggap suatu fungsi keuangan yang mendasar dalam setiap perusahaan. Rekening bank merupakan salah satu aktiva yang berfungsi sebagai pengendali intern terhadap kas perusahaan. Maka dari itu pengelolaan mutasi bank sangat penting sebagai controlling terhadap operasional keuangan perusahaan. Pengelolaan kas di bank ini dapat diawasi dengan melakukan rekonsiliasi bank setiap bulan.

Tujuan peninjauan ini adalah untuk mengetahui bagaimana proses pencatatan mutasi kas di bank serta untuk mengetahui proses penyusunan laporan rekonsiliasi bank pada Koperasi Sejahtera Bersama (KSB) SB Finance Cab. Padjajaran Bogor.

Hasil peninjauan menunjukkan bahwa pencatatan mutasi kas di bank pada Koperasi Sejahtera Bersama (KSB) SB Finance Cab. Padjajaran Bogor dibagi menjadi dua yaitu transaksi operasional penerimaan dana droping dari kantor pusat yang melibatkan beberapa unit operasional di kantor pusat yaitu departemen Keuangan dan Anggaran Kantor Pusat dan Staf Marketing Support serta transaksi operasional pengeluaran dana yang terbagi menjadi pembayaran jasa, pencairan deposito, pencairan pinjaman, dan transfer dana ke kantor pusat.

Rekonsiliasi bank disusun untuk menyesuaikan saldo bank menurut catatan perusahaan berdasarkan data pada rekening koran dari bank dan buku besar bank dari sistem BPR Satu.

Keyword: Mutasi Bank, Rekonsiliasi Bank 


\section{BAB I}

\section{PENDAHULUAN}

\subsection{Latar Belakang}

Melihat kondisi perekonomian dewasa ini, berbagai bentuk badan usaha semakin berkembang sesuai dengan visi dan misi dari masing-masing perusahaan, baik perusahaan swasta maupun perusahaan milik pemerintah sama-sama memberikan pelayanan kepada masyarakat.

Koperasi adalah badan usaha yang beranggotakan orang atau badan hukum yang berlandaskan pada asas kekeluargaan dan demokrasi ekonomi. Kegiatan usaha koperasi merupakan penjabaran dari UUD 1945 pasal 33 ayat (1). Dengan adanya penjelasan UUD 1945 Pasal 33 ayat (1) koperasi berkedudukan sebagai soko guru perekonomian nasional dan sebagai bagian yang tidak terpisahkan dalam sistem perekonomian nasional.

Sebagai salah satu pelaku ekonomi, koperasi merupakan organisasi ekonomi yang berusaha menggerakkan potensi sumber daya ekonomi demi memajukan kesejahteraan anggota. Karena sumber daya ekonomi tersebut terbatas, dan dalam mengembangkan koperasi harus mengutamakan kepentingan anggota, maka koperasi harus mampu bekerja seefisien mungkin dan mengikuti prinsip-prinsip koperasi dan kaidah-kaidah ekonomi.

Mengenai pelayanan perusahaan termasuk koperasi orientasinya tidak sepenuhnya pada orientasi keuntungan, akan tetapi lebih mengutamakan pada tingkat pelayanan dan jasa kepada para pelanggan/masyarakat dengan kualitas pekerjaan yang baik sesuai visi dan misi perusahaan atau koperasi, maka harus ditunjang dengan pengelolaan keuangan yang baik pula.

Di dalam perusahaan, pengelolaan kas yang baik sangatlah penting karena pengelolaan kas dapat dianggap suatu fungsi keuangan yang mendasar dalam setiap perusahaan. Oleh sebab itu, adanya pengelolaan kas yang baik akan membuat kondisi keuangan perusahaan tersebut menjadi sehat. 
Kas merupakan aktiva terlancar yang dimiliki oleh perusahaan. Pada neracapun kas memiliki urutan pertama karena begitu fitalnya akun kas ini. Karena penting pengawasan yang ketatpun diperlukan untuk menghindari adanya kecurangan. Maka dari itu perusahaan perlu untuk menyimpan kas mereka di akun bank sebagai salah satu alat utama yang digunakan perusahaan untuk mengendalikan kas. Misalnya perusahaan seringkali menetapkan bahwa semua penerimaan kas harus disetor ke rekening bank. Begitu juga, perusahaan biasanya menggunakan cek untuk melakukan semua pembayaran kecuali untuk jumlah yang kecil. Bila sistem semacam itu digunakan maka terdapat dua catatan terpisah atas transaksi kas dimana satu catatan di lakukan oleh perusahaan dan satu lagi oleh bank.

Perusahaan dapat menggunakan laporan bank untuk membandingkan transaksi kas yang dicatat dalam catatan akuntansi dengan yang dicatat oleh bank. Saldo kas pada laporan bank biasanya berbeda dari saldo kas menurut catatan akuntansi.

Perbedaan ini bisa disebabkan oleh penundaan pencatatan transaksi oleh salah satu pihak. Misalnya, akan ada pebedaan waktu satu hari atau lebih diantara tanggal penarikan cek dan pembayaran cek oleh bank. Dalam hal ini, perusahaan akan mencatat terlebih dahulu daripada bank sehingga akan menimbulkan perbedaan dalam saldo nantinya.

Perbedaan bisa juga disebabkan salah satunya karena kesalahan yang dilakukan baik oleh bank maupun pihak perusahaan. Contonya cek senilai $\$ 4500$ yang salah dicatat menjadi $\$ 450$ oleh perusahaan dapat menimbulkan selisih nantinya.

Selisih ini kemudian harus disamakan pada akhir periode yang dinamakan rekonsiliasi bank. Laporan rekonsiliasi bank inilah yang menggambarkan perbedaan selisih yang terjadi baik di perusahaan maupun di bank. Pada laporan ini terlihat penyebab perbedaan jumlah nilai transaksi baik yang terletak di perusahaan maupun di bank.

Oleh sebab akun bank ini juga penting adanya dalam sebuah perusahaan maka penulis tertarik untuk membuat Tugas Akhir dengan judul "TINJAUAN

ATAS PENGELOLAAN MUTASI BANK PADA KOPERASI SEJAHTERA BERSAMA (KSB) - SB FINANCE CABANG PADJAJARAN BOGOR".

\subsection{Identifikasi Masalah}

1. Bagaimana proses pencatatan mutasi kas di bank pada Koperasi Sejahtera Bersama Cab. Padjajaran Bogor ?

2. Bagaimana proses penyusunan Laporan Rekonsiliasi Bank pada Koperasi Sejahtera Bersama Cab. Padjajaran Bogor?

\subsection{Maksud dan Tujuan}


Adapun maksud peninjauan yang dilakukan oleh penulis adalah untuk memperoleh data dan informasi mengenai topik Tugas Akhir yang penulis susun, dan mengetahui praktek langsung mengenai pengelolaan mutasi bank pada Koperasi Sejahtera Bersama yang sebelumnya telah penulis pelajari sewaktu kuliah.

Adapun tujuan peninjauan yang dilakukan oleh penulis adalah sebagai berikut:

1. Untuk mengetahui bagaimana proses pencatatan mutasi kas di bank pada Koperasi Sejahtera Bersama Cab. Padjajaran Bogor.

2. Untuk mengetahui bagaimana proses penyusunan laporan rekonsiliasi bank pada Koperasi Sejahtera Bersama Cab. Padjajaran Bogor.

\subsection{Waktu dan Tempat Praktek Kerja}

Kegiatan magang dilaksanakan mulai dari tanggal 01 Februari 2013 s/d 31 Maret 2013 dari pukul 08.00 - 13.00 WIB di SB Building Koperasi Sejahtera Bersama Cab. Padjajaran Bogor, JIn Pajajaran No. 1 Bogor 16151 Jawa Barat telp. (0251) 7560450 (hunting), (0251) 7560451-55, Fax. (0251) 8331226. 


\section{BAB IV \\ SIMPULAN DAN SARAN}

\subsection{Simpulan}

Berdasarkan hasil peninjauan yang telah diuraikan pada bab-bab sebelumnya, maka simpulan yang dapat penulis ambil adalah :

1. Proses pencatatan mutasi kas di bank pada Koperasi Sejahtera Bersama SB Finance Cab. Padjajaran Bogor terbagi menjadi dua transaksi, yaitu transaksi operasional keuangan penerimaan kas di bank dan transaksi operasional keuangan pengeluaran kas di bank. Transaksi operasional keuangan penerimaan kas di bank meliputi Penerimaan Dana Droping dari Kantor Pusat. Proses droping tersebut melibatkan beberapa unit operasional di Kantor Pusat yaitu Departemen Keuangan dan Anggaran Kantor Pusat dan Staf Marketing Support. Setelah dana droping diterima, Kantor Cabang harus segera membukukan penerimaan droping dana dari Kantor Pusat ke Sistem BPR SATU. Proses pencatatan yang dilakukan Kantor Cabang melibatkan beberapa orang yakni Supervisor dan Teller. Dalam melakukan pencatatan droping, kantor pusat dan kantor cabang memiliki pembukuan yang saling terkait. Sedangkan transaksi operasional pengeluaran kas di bank meliputi pembayaran jasa tunai yang nominalnya di atas Rp. 2.500 .000 sehingga dianjurkan menggunakan cek, pembayaran jasa transfer,

pencairan deposito yang nominalnya di atas Rp.2.500.000 sehingga dianjurkan menggunakan cek, pencairan deposito transfer, dan pencairan pinjaman dengan menggunakan cek, dan transfer dana ke kantor pusat. 
2. Proses penyusunan laporan rekonsiliasi bank pada Koperasi Sejahtera Bersama (KSB) SB Finance cabang Padjajaran Bogor yaitu dengan membandingkan antara saldo kas di bank menurut rekening koran dan buku besar perusahaan pada sistem BPR satu. Beberapa hal yang biasanya menyebabkan perbedaan saldo bank menurut rekening koran dengan saldo bank menurut buku besar perusahaan adalah Biaya administrasi yang sudah dibebankan oleh bank tapi belum dicatat oleh perusahaan, Jasa giro yang belum diakui oleh perusahaan, Outstanding check, Kesalahan pencatatan baik yang dilakukan oleh perusahaan maupun bank, retur jasa ataupun pencairan transfer yang belum di input oleh kantor cabang.

\subsection{Saran}

Berdasarkan pembahasan dan simpulan, maka saran yang dapat diberikan penulis antara lain sebagai berikut:

1. Mengingat operasional keuangan perusahaan sudah menggunakan sistem, maka hendaknya pembuatan daftar payroll yang akan dibayarkan kepada nasabah tidak melibatkan terlalu banyak unit operasional, seperti adanya staff marketing support yang bertugas membuat daftar payroll yang akan dibayarkan kepada nasabah. Menurut penulis keberadaan staff ini tidak terlalu dibutuhkan dalam proses pembuatan daftar payroll karena harusnya daftar payroll sudah ada pada sistem, jadi cukup supervisor yang bertugas untuk mencetak daftar tersebut sehingga marketing support bisa fokus terhadap 
tugasnya sebagai marketing. Jadi jobdesk masing-masing di kantor cabang bisa lebih efektif dan efisien.

2. Operasional perusahaan sudah dilaksanakan dengan menggunakan komputerisasi maka ada baiknya sistem yang digunakan dievaluasi secara berkala, karena dalam prakteknya sistem masih mengalami kendala yaitu lamanya proses otorisasi inputan cabang ke kantor pusat yang biasa disebut " $X$ System". $X$ System ini tidak hanya terjadi dalam proses otorisasi tapi juga bisa terjadi ketika pengguna akan melakukan pemindahan menu misalnya dari menu setoran tunai ke tarikan tunai. Dengan adanya masalah pada jaringan ini, maka dapat berpengaruh terhadap jam operasional perusahaan. 


\section{DAFTAR PUSTAKA}

Faud, Moh. Ramly, dan M. Ruslan. 2005. Akuntansi Perbankan. Graha IImu. Yogyakarta.

Hendar dan Kusnadi. 2000. Ekonomi Koperasi. Fakultas Ekonomi Universitas Indonesia. Jakarta.

Ismail. 2011. Akuntansi Bank, Teori dan Aplikasi dalam Rupiah. Kencana. Jakarta

Kieso, Donald E., Jerry J. Weygandt and Terry D. Warfield. 2011. Intermediate Accounting. Wiley : Jhon Wiley \& Sons, Inc.

Mardiasmo. 2000. Akuntansi Keuangan Dasar. Edisi 2, BPFE-Yogyakarta. Yogyakarta.

Reeve, James M., dan Carl S. Warren. 2010. Pengantar Akuntansi- Adaptasi Indonesia. Buku 1, Salemba Empat. Jakarta.

Undang-Undang No. 17 tahun 2012 tentang Koperasi

Djanegara, H.M.S., Triandi, T. and Praktikno, S., 2009. Peranan Audit Operasional dalam Meningkatkan Efektivitas dan Efisiensi Fungsi Pembelian pada PT. Organ Jaya. Jurnal IImiah Ranggagading (JIR), 9(1), pp.1-8.

Djanegara, M.S. and Ivonia, L., 2006. Evaluasi Pengendalian Intern Penjualan Kredit Dalam Meningkatkan Kolektibilitas Piutang pada PT Austindo Nusantara Jaya Finance. Jurnal Umum.

Hidayat, L. and Mhaydaly, S., 2008. Analisis Risiko Dan Arus Kas Terhadap IRR: Studi kasus pada PT. Dharmala Intiland Tbk, PT. Duta Pertiwi Tbk dan PT. Kawasan Industri Jababeka Tbk. Jurnal IImiah Ranggagading (JIR), 8(1), pp.51-58.

Ikatan Akuntansi Indonesia. 2009. Pernyataan Satandar Akuntansi Keuangan. Edisi Revisi. Salemba Empat. Jakarta

Muktiaji, N., 2006. Pengendalian Persediaan Deterministik Multi Item Dengan Potongan Harga Berdasar Jumlah Pesanan Dan Biaya Pesan Gabungan. Jurnal Ilmu Ranggagading, 6(2).

Pamungkas, B., 2008. Akuntabilitas Instansi Pemerintah, Survei Pada Pemerintah Dati II DI Yogyakarta.

Pamungkas, B., 2008. Akuntabilitas Instansi Pemerintah. Survei Pada Pemerintah Dati II DI Yogyakarta.

Pamungkas, B., 2005. Pengaruh Kualitas Peraturan Perundang-undangan, Akuntansi Keuangan Sektor Publik, dan Penerapan Pengawasan terhadap Kualitas Laporan Keuangan Pemerintah dan Akuntabilitas Kinerja Instansi Pemerintah. Disertasi UNPAD. Bandung. Tidak Dipublikasikan.

Purba, J.H.V. and Sulistiono, A., 2013. Pengaruh Pelayanan dan Kualitas Produk Terhadap Loyalitas Pelanggan. Jurnal IImiah Manajemen Kesatuan, 1(1), pp.81-90. 
PT Pos Indonesia (Persero). 2011. Sejarah PT Pos Indonesia (Persero). http://www.posindonesia.co.id

Reeve, James M., Warren, Carl S., Duchac, Jonatahn E. 2009. Pengantar Akuntansi-Adaptasi Indonesia. Salemba Empat. Jakarta

Rosita, S.I. and Rahman, A., 2011. EVALUASI PENERAPAN PEMBIAYAAN MUDHARABAH DAN PENGARUHNYA TERHADAP LABA PERUSAHAAN Studi Kasus pada PT Bank Muamalat Indonesia Tbk, Cabang Bogor. Jurnal Ilmiah Ranggagading, 11(1), pp.57-64.

Stice, Earl K., Stice, James D., Skousen K., Fred. 2004. Akuntansi Intermediatte. Edisi Lima Belas. Salemba Empat. Jakarta

Soemarso. 2004. Akuntansi Suatu Pengantar. Edisi Lima (Revisi). Salemba Empat. Jakarta

Sofyan Syafri Harahap. 2005. Teori Akuntansi. Edisi Revisi. PT Raya Grafindo Persad. Jakarta

Warren, Carl S., Reeve, James M., Fess, Philip E. 2008. Pengantar Akuntansi. Salemba Empat. Jakarta

Weygandt, Jerry J., Kieso, Donald E., Kimmel, Paul D. 2007. Pengantar Akuntansi. Edisi Tujuh. Salemba Empat. Jakarta

Weygandt, Jerry J., Kieso, Donald E., Kimmel, Paul D. 2011. Financial Accounting IFRS Edition. Wiley : John Wiey \& Sons, Inc. 